\title{
The Effect of Public Law 111-216 on Collegiate Flight Programs: Perceptions of Aviation Faculty and Flight Center Personnel
}

\author{
Chad L. Depperschmidt, Timm J. Bliss, and Mallory K. Casebolt \\ Oklahoma State University
}

\begin{abstract}
In response to the 2009 Colgan 3407 airline crash and ensuing public concern, Public Law 111-216: The Airline Safety and Federal Aviation Administration Extension Act of 2010 was signed into law on August 1, 2010. This legislation mandated significant changes to the aviation and airline industries. Among these changes, an increase in pilot qualification standards was enforced for pilots seeking employment with US air carriers. This study explores the perceptions of aviation faculty members and flight center personnel at fouryear collegiate flight training programs in the US regarding the effect of PL 111-216. Results of this national study indicate the majority of respondents believe PL 111-216 will have an adverse effect on collegiate aviation flight students, collegiate aviation flight training programs and the US air carrier industry. This study also revealed the perception that collegiate flight students will begin to pursue flight careers (non-US airline or corporate aviation) that are not directly impacted by PL 111-216.
\end{abstract}

\section{Introduction}

Any air carrier accident resulting in passenger or crew fatalities receives a high volume of attention from media and flying public. Each air carrier accident is closely analyzed and reviewed in an effort to mitigate the risk of repetition of the same type of accident. After investigation, regulatory modifications are often made related to specific events that contributed to the accident. In the name of safety, all shareholders strive to ensure that flying passengers will safely arrive at their destinations. These changes are intended to improve the safety of flight but rarely do they have sweeping affects across the industry. However, the aftermath of the 2009 crash of Colgan Air Flight 3407 was different.

In February of 2009, Colgan Air Flight 3407 crashed in Buffalo, New York. This tragic end to flight 3407 resulted in the death of 45 passengers, four crew members and one person on the ground (Pasztor, 2009). This crash resulted in an unusually high level of scrutiny from the media due to the National Transportation Safety Board's (NTSB) report, which in part, focused on failed flight checks, challenging living arrangements that require crew to commute across the country, and low pay for the flight crew (Garrison, 2010). This tragedy triggered a massive overhaul of airline safety and pilot qualifications that now affects the entire US air carrier industry. The magnitude of these changes are evident in the comments of Collins (2014) "the crash of Colgan 3407 brought on the all-time most egregious case of smoke and flames rulemaking by the FAA, among other things, establishing new standards for first officers" (para. 1). President Obama, on August 1, 2010, signed into law Public Law 111-216: The Airline Safety and Federal Aviation 
Administration Extension Act of 2010 (Airline Safety and Federal Aviation Administration Extension Act of 2010, 2012).

Particularly concerning to current and aspiring pilots and pilot training organizations, these new standards would drastically change the expectations and progression of pilots seeking employment from US air carriers. These new standards would require pilots that occupy the flight deck of a commercial airliner to hold an Airline Transport Pilot (ATP) Certificate, the highest attainable airmen certificate requiring 1,500 hours of flight time. This represents more than 1,000 hours of additional flight time than previous standards that pilots must hold a commercial certificate and 250 hours of total flight time (Blair \& Freye, 2012; Collins, 2014). These new standards went into effect on August 1, 2013, three years after the law was enacted (Airline Safety and Federal Aviation Administration Extension Act of 2010, 2012).

As a result of PL 111-216, a new pilot qualification, Restricted ATP (R-ATP) was created to assist aspiring airline pilots to be eligible to operate in a commercial airliner before earning the 1,500 flight hours in certain circumstances. These options and circumstances for the R-ATP are (Radtke, 2015):

- 750 flight hours for military pilots

- 1,000 flight hours for graduates holding a bachelor's degree with an aviation major from an approved school

- 1,250 flight hours for graduates holding an associate degree with an aviation major from an approved school

Under this new qualification, pilots are now able to acquire pilot certification from approved organizations or institutions with slightly less pilot flight time requirements than the ATP Certificate or 1,500 hours.

Since enactment of PL 111-216 in 2010, pilot training organizations have been closely following the details in an effort to stay informed and adjust so they may offer their students and prospective students the best flight training opportunities possible. Collegiate flight training programs have been particularly concerned with these new standards and the potential effects to their institution's pilot training. Many collegiate flight training programs have voiced concern that increasing the pilot qualification standards will force student pilots to acquire many more flight hours that are not typically included in their academic flight training programs (University Aviation Association, 2012). Furthermore, to be eligible to offer the R-ATP, collegiate flight training programs must seek approval from the FAA by an R-ATP application process.

Recent academic research studies regarding PL 111-216 have all expressed significant concern regarding the application of these new standards, the potential negative effect to collegiate flight program current and prospective students, alterations to the career path for aspirating pilots and the long term effects collegiate flight training programs (Bjerke E. \& Malott, 2011; Christensen C. \& Card. K. A., 2014; Depperschmidt, C. L., 2013). Additionally, many individuals from industry have voiced concern that long-term effects of PL 111-216 may have negative effects to the aviation industry (contributing to a looming 
pilot shortage, discouraging future generations from considering commercial pilot as a career choice) or that the intended purpose of the legislation to create a safer industry with more capable pilots by requiring additional certification with increased total flight time is misguided and ineffective (Garfield, 2014; Romero, 2013; Schneider, 2013).

As with any change, there is a possibility for unknown or unintended consequences. PL 111-216 is no exception. As this new legislation is enforced, it is important for all stakeholders of the US aviation industry to closely follow the effects and possible consequences. Collegiate flight training programs represent a significant portion of supporters to the early stages of the pilot training cycle. Members of these programs (aviation faculty and flight center personnel) are well positioned to quickly interpret and identify the effects and trends related to PL 111-216, especially as they directly relate to collegiate flight training programs.

PL 111-216 created significant change and challenges for collegiate flight training programs. As collegiate flight training programs, it is important to understand these challenges so they may collectively and individually adapt to offer the best flight training opportunities possible for their students. In an effort to better understand how PL 111-216 is affecting collegiate flight training programs, this study explores the perceptions of aviation faculty members and flight center personnel regarding the effect and challenges five years after enactment and two years after enforcement of PL 111-216.

\section{Methodology}

To better understand the effects and challenges of PL 111-216 to collegiate flight training programs, the following research questions were used to guide this study:

1. What effect has PL 111-216 had on collegiate flight programs?

2. What effect has PL 111-216, specifically the R-ATP requirement, had on collegiate flight students and their career aspiration of professional flight?

\section{Research Population}

To answer these questions, this study sought the perceptions of aviation faculty and flight center personnel (director, manager, chief flight instructor, assistant chief flight instructor) of four-year collegiate flight training programs in the United States that offer flight training for academic credit of a bachelor's degree in aviation.

Potential participants for this study were identified by several different measures. First, all educational institutions who are 2015 institutional members of the University Aviation Association (UAA) were considered for this study. This represented a total of 96 institutional members. Of these 96 institutional members, the authors conducted an internet search of each institution's website to determine if they offered flight training associated to earning a bachelor's degree in professional pilot, or flight. Of these 96 original institutional members, 41 institutions offered flight training related to a bachelor's degree in professional pilot, or flight. The authors reviewed the faculty/staff websites of these 41 institutions to identify aviation faculty and flight center personnel. This final measure 
resulted in this study's population of 262 individual aviation faculty or flight center personnel.

The authors sent the 262 identified aviation faculty members and flight center personnel a solicitation email inviting them to complete a voluntary electronic research instrument with a provided electronic survey link. After approximately two weeks, a second reminder solicitation email was sent to all 262 potential participants. After approximately one month, the survey was deactivated and results were processed for this study. Of the 262 potential participants, 122 completed all questions of the survey. In addition to the 122 respondents, one participant chose to not participate and 10 did not complete all questions. In an effort to standardize respondent results, these 11 participants responses (not to participate and partial responses) were not included in the analysis or results of this study. The final response rate for this study was 122 participants (46.5\%) of 262 potential participants.

\section{Research Instrument}

Developed by the authors, the research instrument was created to solicit demographic, perception and comment information from the respondents regarding issues related to the effect of PL 111-216. Demographic questions sought information regarding enrollment trends, size of program, type of employment and if institutions were approved to offer the R-ATP. Perception questions were offered in Likert-scale statements in an ordinal measurement pattern that offered respondents the options of: Strongly Agree, Agree, Disagree, or Strongly Disagree. For this study, the authors used a 0-4, forced-response, Likert-Scale. The forced-response Likert-scale does not offer a central or neutral choice and forces the respondents to agree or disagree with the statement (Trochim, 2006). The last section of the research instrument was an open text box where respondents were asked to include any comments or concerns they had regarding PL 111-216 and its effect on their collegiate flight program and/or students. Permission to conduct this study and solicit this research instrument was approved by the Institutional Review Board at Oklahoma State University (approval \# ED-15-71).

\section{Limitations of Study}

Limiting to this study was the volunteer participation of the respondents. Results of this study reflect the 122 participating respondents who were available and willing to complete the electronic research instrument. Further, results to this study are limited to the perceptions of faculty and flight center personnel of UAA member institutions.

\section{Analysis}

The Likert-scale statements were analyzed using Cronbach's alpha $(\alpha)$ reliability test to measure internal consistency. To measure internal consistency, Cronbach's $\alpha$ determines how all items on a test are related to all other items and the total test (Gay, Mills, \& Airasian, 2006). George and Mallery (2003) established the following Cronbach's $\alpha$ acceptance scale: " $\geq .9$ - Excellent; $\geq .8$ - Good; $\geq .7$ - Acceptable; $\geq .6$ - Questionable; $\geq .5$ - Poor; and $\geq .5$ - Unacceptable" (p. 231). To analyze the results of this study, all data 
was inputted into an Excel spreadsheet and then imported into SPSS version 21.0. This resulted in an overall Cronbach's alpha value of .801 representing a level of good based on the George and Mallery scale. This study also applied descriptive statistics in analysis of the data. Standard Deviation, a type of descriptive statistic, is used as a measure of variability in data analysis (Fraenkel \& Wallen, 2006; Gay, Mills, \& Airasian, 2006). In the results section of this study, standard deviation is indicated as SD for the demographic and Likert-statement results.

\section{Results}

\section{Demographic}

Respondents were asked to identify their position of academic employment at their educational institution. Choices for this question were Aviation Faculty or Flight Center Personnel (Director, Manager, Chief/Assistant Chief Flight Instructor). Table 1 indicates that the majority of respondents were aviation faculty $(71 \%)$.

Table 1

Respondent Academic Employment

\begin{tabular}{l|l|l|l} 
& Responses & Percentage & SD \\
\hline Aviation Faculty & 87 & $71 \%$ & 0.45 \\
$\begin{array}{l}\text { Flight Center } \\
\text { Personnel }\end{array}$ & 35 & $29 \%$ & 0.45 \\
\hline Total & 122 & $100 \%$ &
\end{tabular}

In addition, the research instrument asked respondents to identify the approximate number of student pilots enrolled in their collegiate flight program and what enrollment trends they have experienced since enforcement of PL 111-216 in 2013. Tables 2 and 3 detail the respondents' answers to these two questions.

Table 2

\section{Student Pilot Enrollments}

\begin{tabular}{l|l|l|l} 
Enrollments & Responses & Percentage & SD \\
\hline $1-50$ & 8 & $7 \%$ & \\
$51-100$ & 34 & $28 \%$ & 1.63 \\
$101-150$ & 25 & $20 \%$ & 1.63 \\
$151-200$ & 21 & $18 \%$ & 1.63 \\
$201-250$ & 9 & $7 \%$ & 1.63 \\
251 or more & 25 & $20 \%$ & 1.63 \\
\hline Total & 122 & $100 \%$ &
\end{tabular}


Table 3

Enrollment Trends since Enforcement of PL 111-216

\begin{tabular}{l|l|l|l} 
Enrollment Trend & Responses & Percentage & SD \\
\hline Increasing & 36 & $29 \%$ & 0.86 \\
Decreasing & 30 & $25 \%$ & 0.86 \\
Unchanged & 56 & $46 \%$ & 0.86 \\
\hline Total & 122 & $100 \%$ & \\
\hline & & &
\end{tabular}

The last demographic question asked respondents if their collegiate flight training program was approved by the FAA to offer the R-ATP certification. Table 4 indicates a strong majority, $77 \%$, of respondents are from a collegiate flight program that is approved for the R-ATP certificate.

Table 4

Programs Approved for R-ATP

\begin{tabular}{l|l|l|l}
$\begin{array}{l}\text { R-ATP } \\
\text { Approval }\end{array}$ & Responses & Percentage & SD \\
\hline Yes & 94 & $77 \%$ & 0.51 \\
No & 24 & $20 \%$ & 0.51 \\
Under Review & 4 & $3 \%$ & 0.51 \\
\hline Total & 122 & $100 \%$ &
\end{tabular}

\section{Likert-Scale Statements}

To explore the perceptions of aviation faculty and flight center personnel, the survey instrument solicited responses to 13 Likert-scale statements regarding PL 111-216 and its potential effect on collegiate flight students, collegiate flight training programs and the US air carrier industry. Table 5 lists the results of the Likert statements related to the effect of PL 111-216 on collegiate flight students. 
Table 5

Perceptions of Effect Regarding Students

\begin{tabular}{|c|c|c|c|c|}
\hline Likert Statement & $\begin{array}{l}\text { Strongly } \\
\text { Agree }\end{array}$ & Agree & Disagree & $\begin{array}{l}\text { Strongly } \\
\text { Disagree }\end{array}$ \\
\hline $\begin{array}{l}\text { Our current flight students have expressed } \\
\text { concerns regarding the effect PL 111-216 } \\
\text { will have on their career goal of aviation } \\
\text { flight. }\end{array}$ & $\begin{array}{c}64 \\
(52 \%)\end{array}$ & $\begin{array}{c}47 \\
(39 \%)\end{array}$ & $\begin{array}{c}8 \\
(6 \%)\end{array}$ & $\begin{array}{c}3 \\
(3 \%)\end{array}$ \\
\hline $\begin{array}{l}\text { The required R-ATP certificate (minimum } \\
\text { of } 1,000 \text { flight hours) will discourage some } \\
\text { of our current flight students to } \\
\text { continue/complete their four-year collegiate } \\
\text { flight degree due to the financial obligation } \\
\text { of additional flight costs. }\end{array}$ & $\begin{array}{c}25 \\
(20 \%)\end{array}$ & $\begin{array}{c}67 \\
(55 \%)\end{array}$ & $\begin{array}{c}28 \\
(23 \%)\end{array}$ & $\begin{array}{c}2 \\
(2 \%)\end{array}$ \\
\hline $\begin{array}{l}\text { Since implementation of PL 111-216 } \\
\text { (August 2013), our flight students have } \\
\text { increasingly pursued other undergraduate } \\
\text { aviation degree options other than } \\
\text { flight/professional pilot. }\end{array}$ & $\begin{array}{c}13 \\
(11 \%)\end{array}$ & $\begin{array}{c}59 \\
(48 \%)\end{array}$ & $\begin{array}{c}45 \\
(37 \%)\end{array}$ & $\begin{array}{c}5 \\
(4 \%)\end{array}$ \\
\hline $\begin{array}{l}\text { Our collegiate aviation flight program's } \\
\text { aviation faculty and/or flight center } \\
\text { personnel believe that PL } 111-216 \\
\text { requirement of the R-ATP certificate will } \\
\text { effectively produce a more experienced and } \\
\text { employable collegiate pilot. }\end{array}$ & $\begin{array}{c}1 \\
(1 \%)\end{array}$ & $\begin{array}{c}13 \\
(13 \%)\end{array}$ & $\begin{array}{c}55 \\
(45 \%)\end{array}$ & $\begin{array}{c}50 \\
(41 \%)\end{array}$ \\
\hline
\end{tabular}

As indicated by Table 5 responses, the majority of respondents expressed concern that PL 111-216 will have an adverse effect on students. More than $90 \%$ of respondents indicate students have expressed concern regarding their career goals, and $75 \%$ of respondents believe PL 111-216 will discourage students to complete or continue their collegiate flight degree. While the majority of respondents indicated students are concerned or challenged to continue their academic pursuit and career goals, they also strongly indicated that new pilot standard will not produce a more experienced or employable pilot. When asked to respond to the following statement; Our collegiate aviation flight program's aviation faculty and/or flight center personnel believe that PL 111-216 requirement of the $R$-ATP certificate will effectively produce a more experienced and employable collegiate pilot, $86 \%$ of respondents disagreed or strongly disagreed.

To examine potential effects to collegiate flight training programs, respondents were asked to respond to several Likert statements that addressed the potential effect of PL 111216 on their collegiate flight training program. Results of the responses to these statements are listed in Table 6.

Table 6 further expresses concerns by the respondents regarding the effect of PL 111216 on their collegiate flight training program. The majority of respondents were concerned 
that retention of current students and recruitment of potential students would be negatively affected by PL 111-216. Respondents strongly agreed or agreed (84\%) that their aviation faculty and flight center personnel have concerns regarding the effect PL 111-216 will have on their flight program and 82\% of respondents strongly agreed or agreed that PL 111-216 will have a negative effect on their flight students and their collegiate flight program.

Table 6

Perceptions of Effect Regarding Collegiate Flight Training Programs

\begin{tabular}{|c|c|c|c|c|}
\hline Likert Statement & $\begin{array}{l}\text { Strongly } \\
\text { Agree }\end{array}$ & Agree & Disagree & $\begin{array}{l}\text { Strongly } \\
\text { Disagree }\end{array}$ \\
\hline $\begin{array}{l}\text { Our collegiate aviation flight program has } \\
\text { concerns that PL } 111-216 \text { will negatively } \\
\text { affect the retention rate of our current } \\
\text { flight/professional pilot students. }\end{array}$ & $\begin{array}{c}21 \\
(17 \%)\end{array}$ & $\begin{array}{c}64 \\
(52 \%)\end{array}$ & $\begin{array}{c}36 \\
(30 \%)\end{array}$ & $\begin{array}{c}1 \\
(1 \%)\end{array}$ \\
\hline $\begin{array}{l}\text { Our collegiate aviation flight program has } \\
\text { concerns that PL } 111-216 \text { will negatively } \\
\text { affect the recruitment of prospective } \\
\text { flight/professional pilot students. }\end{array}$ & $\begin{array}{c}67 \\
(55 \%)\end{array}$ & $\begin{array}{c}31 \\
(25 \%)\end{array}$ & $\begin{array}{c}21 \\
(17 \%)\end{array}$ & $\begin{array}{c}3 \\
(3 \%)\end{array}$ \\
\hline $\begin{array}{l}\text { Our collegiate aviation flight program's } \\
\text { aviation faculty and/or flight center } \\
\text { personnel have concerns regarding the } \\
\text { effect PL 111-216 will have on our flight } \\
\text { program. }\end{array}$ & $\begin{array}{c}40 \\
(33 \%)\end{array}$ & $\begin{array}{c}63 \\
(51 \%)\end{array}$ & $\begin{array}{c}16 \\
(13 \%)\end{array}$ & $\begin{array}{c}3 \\
(3 \%)\end{array}$ \\
\hline $\begin{array}{l}\text { Overall, PL 111-216 will have a negative } \\
\text { effect on our flight students and our } \\
\text { collegiate flight program. }\end{array}$ & $\begin{array}{c}31 \\
(25 \%)\end{array}$ & $\begin{array}{c}57 \\
(47 \%)\end{array}$ & $\begin{array}{c}33 \\
(27 \%)\end{array}$ & $\begin{array}{c}1 \\
(1 \%)\end{array}$ \\
\hline $\begin{array}{l}\text { As a result of PL } 111-216 \text { implementation, } \\
\text { our college/university administration has } \\
\text { expressed concern regarding the future } \\
\text { viability of our collegiate flight program. }\end{array}$ & $\begin{array}{c}13 \\
(11 \%)\end{array}$ & $\begin{array}{c}50 \\
(41 \%)\end{array}$ & $\begin{array}{c}48 \\
(39 \%)\end{array}$ & $\begin{array}{c}11 \\
(9 \%)\end{array}$ \\
\hline
\end{tabular}

The last set of Likert statements were intended to investigate the potential effect of PL 111-216 on the US air carrier industry. Results of the responses to these statements are provided in Table 7. Outcomes of respondent's perceptions regarding the industry were similar to those regarding students and collegiate flight training programs by a strong majority concern for an adverse effect as a result of PL 111-216. When asked if PL 111216 will improve the overall safety of the US air carrier industry, 92\% of respondents disagreed or strongly disagreed that their students have stated that PL 111-216 will improve the overall safety of the US air carrier industry; and 93\% of respondents indicated that aviation faculty or flight center personnel disagreed or strongly disagreed that PL 111-216 will improve the overall safety of the US air carrier industry. The majority of respondents (87\%) also believe that PL 111-216 will contribute to a pilot shortage and $88 \%$ strongly agree or agree that overall, PL 111-216 will have a negative effect on the US air carrier industry. 
Table 7

Perceptions of Effect Regarding the US Air Carrier Industry

\begin{tabular}{l|c|c|c|c} 
Likert Statement & $\begin{array}{l}\text { Strongly } \\
\text { Agree }\end{array}$ & Agree & Disagree & $\begin{array}{c}\text { Strongly } \\
\text { Disagree }\end{array}$ \\
\hline $\begin{array}{l}\text { Our current flight students have stated that } \\
\text { PL 111-216 (required R-ATP certificate) }\end{array}$ & 2 & 7 & 65 & 48 \\
$\begin{array}{l}\text { will improve the overall safety of the US } \\
\text { air carrier industry. }\end{array}$ & $(2 \%)$ & $(6 \%)$ & $(53 \%)$ & $(39 \%)$ \\
$\begin{array}{l}\text { Our collegiate aviation flight program's } \\
\text { aviation faculty and/or flight center } \\
\text { personnel believe that PL 111-216 } \\
\text { (required R-ATP certificate) will improve }\end{array}$ & $(1 \%)$ & $(6 \%)$ & $(47 \%)$ & $(46 \%)$ \\
the overall safety of the US air carrier & & & & \\
industry. & & & \\
$\begin{array}{l}\text { Our collegiate aviation flight program's } \\
\text { aviation faculty and/or flight center } \\
\text { personnel believe that PL 111-216 } \\
\text { (required R-ATP certificate) will reduce the }\end{array}$ & 57 & 49 & 16 & 0 \\
$\begin{array}{l}\text { number of employable pilots available to } \\
\text { the US air carrier industry; contributing to } \\
\text { the concern of a projected US pilot } \\
\text { shortage. }\end{array}$ & $(47 \%)$ & $(40 \%)$ & $(13 \%)$ & $(0 \%)$ \\
$\begin{array}{l}\text { Overall, PL 111-216 will have a negative } \\
\text { effect on the US air carrier industry. }\end{array}$ & 47 & 61 & 12 & 2 \\
\end{tabular}

\section{Discussion}

It is probable that many stakeholders in the US aviation industry, especially in collegiate flight training programs, will not be overly surprised by the findings of this study. Many have continually voiced concern over recent legislation, increased standards and the potential effect to collegiate flight training and the aviation industry. This was especially true as collegiate aviation training programs speculated the outcome of this legislation prior to the release of the Notice of Proposed Rulemaking (NPRM) of The Airline Safety and Federal Aviation Administration Extension Act of 2010. However, five years after enactment and two years after enforcement of PL 111-216, these concerns remain very strong. As indicated by the results of this study, there are significant concerns for current and prospective flight students, collegiate flight training and the US air carrier industry as a result of PL 111-216.

PL 111-216 remains a passionate issue that continues to be a concern for aviation faculty and flight center personnel of collegiate flight training programs. The last section of the research instrument for this study offered respondents the opportunity to offer personal comments or concerns regarding PL 111-216. Many respondents expressed very strong 
opinions and reiterated many themes explored by the research instrument. However, several new themes emerged as points of concern or interest regarding PL 111-216.

Several respondents indicated that while student pilot enrollment since enforcement of PL 111-216 had increased, this was due to a significant increase in flight students of nonUS citizenship. One respondent indicated concern that collegiate flight training programs who do not have a means to train non-US citizens will suffer competitively after enforcement of PL 111-216. This indicates that in a new climate after PL 111-216, collegiate flight training programs could find a competitive advantage to pursue and train students that seek professional flight careers outside the US that are not affected by PL 111-216. Several also indicated that while enrollment of non-US citizen students have increased, they do not expect US student enrollment to increase due to PL 111-216. Related to this issue, respondents indicated that US student pilots will increasingly seek career opportunities outside of the US as a result of PL 111-216. Also related to this, many respondents indicated an increasing interest of students to seek pilot careers in corporate aviation or Part 135 operators that are not affected by the increased pilot standards of PL 111-216.

It was also recognized by several respondents that a root cause of this issue is related to pilot pay. It was indicated that this problem could be largely solved by increasing the starting salary range of regional pilots and/or decreasing the flight students' financial investment regarding their collegiate flight training costs.

There were also several positive reflections offered by respondents related to the impact of PL 111-216. These were related to two different aspects. Several respondents indicated that approval from the FAA to offer the R-ATP gave them a competitive flight training advantage over most or all competing flight training options in their area. Secondly, several respondents indicated the enforcement of increased pilot standards has resulted in a dramatic increase of the longevity of their CFI's tenure as they seek to acquire additional flight hours. This reduction in CFI turnover and increase in flight training consistency was a welcomed change to several respondents.

Finally, many respondents questioned the effectiveness of the increased standards and challenged that an increase in flight hours at this stage of a student pilot's training would not improve piloting skill. The continued question of "quality vs. quantity" was also expressed. Respondents indicated that the new legislation was misguided in its application since the fault of Colgan 3407 was not as a result of fewer than 1,500 flight hours or lack of an ATP certification from either pilot.

It will take many years to conclude the final effect of PL 111-216 on collegiate flight training programs and the US air carrier industry. However, continued interest and caution is necessary from collegiate aviation stakeholders. In order to offer their flight students the best professional pilot employment opportunities and the US air carrier industry the best qualified pilot applicants, it is vital that collegiate aviation stakeholders continue to voice concern and be involved in the regulatory processes. This would include proposes for necessary regulatory change or active involvement in any legislation that may further affect 
this issue. Perhaps collegiate aviation stakeholders will see continued change or adjustment regarding PL 111-216 in the future. As several respondents indicated, Congress will eventually be forced to fix their mistake and retract or adjust the legislation related to the increase of pilot certification standards of PL 111-216. 


\section{References}

Airline Safety and Federal Aviation Administration Extension Act of 2010, 216 C.F.R. (2012). Retrieved from http:/www.faa.gov/regulations_policies/rulemaking/recently_published/media/2120AJ67NPRM.pdf

Bjerke, E. \& Malott, D. (2011). Impacts of public law 111-216: will the flight instructor career path remain a viable option for aspiring airline pilots?. Collegiate Aviation Review, 29 (1), 1-9.

Blair, J. \& Freye, J. (2012). Flight Training Capacity in the Context of Recent Legislation: An Examination of the impacts of Reduced Training Capacity, and the Declining Rates of Airmen Certification. National Association of Flight Instructors. Retrieved from http:/www.nafinet.org/whitepaper.aspx

Christensen, C. \& Card, K.A. (2014). Specialized aviation flight accreditation under public law 111-216: aviation program administrators' perceptions. Collegiate Aviation Review, 32 (2), 35-50.

Collins, Richard. (2014, March 28). Air Facts Journal. A double tragedy: colgan flight 3407. Retrieved from http:/airfactsjournal.com/2014/03/double-tradegy-colgan-airflight-3407/

Depperschmidt, C.L. (2013). Public Law 111-216: Effects of new legislation on collegiate aviation flight training programs. Collegiate Aviation Review, 31 (1), 1-16.

Fraenkel, J. R., \& Wallen, N. E. (2006). How to design and evaluate research in education. New York, NY: McGraw Hill.

Garfield, Robynn. (2014, February 17). National pilot shortage has local impact. Retrieved from: http://www.ksl.com/?nid=148\&sid=28741972

Garrison, Peter. (2010, May 27). Flying Magazine. Aftermath: The Mystery of Colgan 3407. Retrieved from http://www.flyingmag.com/safety/accidentinvestigations/aftermath-mystery-colgan-3407.html

Gay, L.R., Mills, G.E., \& Airasian, P. (2006). Educational Research: Competencies for Analysis and Applications ( $8^{\text {th }}$ Ed.). Upper Saddle River, New Jersey: Pearson Prentice Hall.

George, D., \& Mallery, P. (2003). SPSS for Windows step by step: A simple guide and reference. 11.0 update $\left(4^{\text {th }}\right.$ ed.). Boston: Allyn \& Bacon. 
Pasztor, A. (2009, May 11). The Wall Street Journal. Captain's training faulted in air crash that killed 50. Retrieved from http://online.wsj.com/article/SB124200193256505099.html

Radtke, E. (2015, March 4). Sporty's Pilot Shop. New ATP Certification Requirements: A Pilots Guide. Retrieved from: http://learntoflyhere.com/2015/03/04/new-atpcertification-requirements

Romero, Clyde. (2013, September 30). Aviation Week \& Space Technology. Hard-core training. Retrieved from: http://awin.aviationweek.com/articlesstory/articlesprint.aspx?id=fc6f3920

Schneider, Jeff. (2013, September 9). Aviation Week \& Space Technology. New pilot requirements are misguided. Retrieved from: http://awin.aviationweek.com/articlesstory/articlesprint.aspx ?id=defa04f2-a9b3

Trochim, Wiliam M.K. (2006). Research Methods Knowledge Base. Retrieved from http://www.socialresearchmethods.net/kb/scallik.php

University Aviation Association. (2012). Response to Docket Number FAA-2010-0100. Board, N. T. (2009). Loss of control on approach. Washington D.C.: National Transportation Safety Board. 